\title{
An Approach to the Chemosystematics of the Genus Cucumis L
}

\author{
A. J. A. PETRUS \\ Department of Chemistry, Kanchi Mamunivar Centre for Post-Graduate \\ Studies (Autonomous), Puducherry - 605 008, India. \\ http://dx.doi.org/10.13005/ojc/300117
}

(Received: January 30, 2014; Accepted: February 26, 2014)

\begin{abstract}
Phylogenetic relationships in the order Cucurbitales as well as the phylogeny and classification of its taxonomically most problematic family, Cucurbitaceae, have been the focus of several studies. Taxonomists over the years have differed on the delimitation of Cucumis L. and numerous taxonomic treatments have been proposed since the pioneering work of Linnaeus (1753). Using maximum parsimony, maximum likelihood, and Bayesian inference analyses of sequence data from the nuclear and chloroplast genomes, the genus Cucumis has recently been recircumscribed. Among the various chemical classes elaborated in plants, the foliar phenolics express greater stability in general and contribute significantly to the chemosystematics of both, angiosperms and gymnosperms. Hence, it is felt that an evaluation of the available literature on the foliar flavonoid constitution of the recently defined Cucumis would be relevant. This paper, therefore, analyses the distribution of the phytophenols in the taxa to ascertain the characteristically common foliar marker biochemical of the genus in addition to an attempt to justify the inclusion of the genus Mukia within Cucumis.
\end{abstract}

Key words: Cucurbitaceae, Cucumis, Mukia, Phytophenols, Chemosystematics.

\section{INTRODUCTION}

Cucurbitaceae is a family of about 120 genera and over 900 species, widely distributed in tropical and subtropical regions of Africa including Madagascar, South, Southeast and East Asia, Australia as well as Central and South America ${ }^{1,2}$. The cucurbits are also among the most diverse plant families, cultivated and naturalised worldwide in a variety of environmental conditions. These include some of the earliest cultivated food plants in both the Old and the New World tropics and subtropics. Examples of some of the World's most important vegetable crops are cucumber (Cucumis sativus), melon (Cucumis melo L.), West Indian Gherkin (Cucumis anguria), pumpkins and squashes (Cucurbita moschata and C. mixta), red pumpkin (Cucurbita maxima), water melon (Citrulus vulgaris), loofah (Luffa acutangula, L. cylindrica), bottle gourd (Lageneria siceraria), snake gourd (Trichosanthes cucumerina var. anguina), bitter gourd (Momordica charantia) and pepitos (Cucurbita pepo). A number of them are used since antiquity not only as food, but also in folk medicine, health-care and cosmetology. Notable medicinal applications include their use in the treatment for diabetes, bronchial and respiratory 
ailments as well as in the oral health care and as an abortifacient ${ }^{3.4}$. Gourds also find use as containers and as resonators in musical instruments such as the sitar.

The genus Cucumis (Cucurbitaceae) comprises of some 38 African/Indian Ocean species, 19 Asian, and six Australian/ New Guinean species. Most of the ca. 63 species of Cucumis, presently known are monoecious annuals, but dioecious mating systems and a perennial habit evolved several times within the genus ${ }^{5}$. Formerly, Cucumis L. was a more narrowly defined genus ${ }^{6}$. Based on the recent molecular-phylogenetic findings ${ }^{7,8}$, the species of the genera Cucumella Chiov., Dicaelospermum C.B.Clarke, Mukia Arn., Myrmecosicyos C.Jeffrey, and Oreosyce Hook.f. are now transferred into a more broadly defined Cucumis ${ }^{9,10}$. In the context of the present nuclear and chloroplast DNA data-based recircumscribtion of Cucumis, an examination of the relevance of the chemotaxonomic significance of the marker phenolics has been attempted for the first time in this paper.

\section{Biosystematics}

In the traditional systems of taxonomy, morphological traits are commonly used for classifications. However, for delimiting those taxa that exhibit morphological/cytological similarities or whose morphological characters show reticulate relations, chemical data in conjunction with those drawn from other approaches (say, morphological, cytological, embryological, anatomical and molecular) are frequently resorted to resolve the issue and to establish phylogenetic relations at interspecific, intergeneric and family levels ${ }^{11,12}$.

Chemical characters may be broadly categorized into visible traits, micromolecular, and macromolecular. Compared to the very few visible characters, such as starch grains, raphides, lapachols and silica that have limited usage in taxonomy, the micro- and macro-molecules prove to be important taxonomic tools ${ }^{13}$. Micromolecular characters relate to the low molecular weight secondary metabolites belonging to various chemical classes, such as phenolic, alkaloid, terpenoid, cyanogenic, free amino acid, lipid and others. Examples of macromolecules offering such informations include certain proteins, DNA and RNA. Though chemical characters offer themselves as important taxonomic tools, some of them, for instance, alkaloids and proteins are susceptible to change with regard to changing environmental conditions or ontogeny. Plant parts of the same physiological age should, therefore, be used for comparative analysis.

\section{Phytophenols}

Phytophenols are the ubiquitous class of bioactive constituents of the human diet, manifesting both nutritional and health benefits, mediated largely by their redox property, reactive species-scavenging and metal chelating capacities ${ }^{14-15}$. They are thus capable of mitigating oxidative stress-induced tissue damage associated with chronic diseases. Structurally, plant phenolics are a diversified group of plant-derived molecules, originated from the pentose phosphate, shikimate and phenylpropanoid pathways. This class of secondary metabolites are produced by the plant kingdom, including certain algae and specific insects. In plants, they are distributed throughout most tissues, including the flowers, roots, seeds and leaves, with the foliar phenolics expressing greater stability ${ }^{16}$. Plant phenolics are characterized by the presence of at least one aromatic ring with one or more hydroxyl groups directly bonded to the ring. They range from the naturally occurring simple, low molecular weight, single-aromatic-ring compounds to the large and complex tannins and derived-polyphenols. The most productive plant metabolic route, in terms of the number of phenolic substances it produces, is the one that leads to the flava-/flavo-noids, a $\mathrm{C}_{6}$ $-\mathrm{C}_{3}-\mathrm{C}_{6}$ framework with close to 10,000 structures characterised to date. Flavonoids, because of their easy isolation, identification, stability and occurrence in different structural forms, have been used extensively for differentiating various species, establishing relationships at inter-generic and subfamilial levels and solving taxonomic problems ${ }^{13}$.

\section{Phylogenetic systematics of Cucumis}

Phylogenetic relationships in the order Cucurbitales as well as the phylogeny and classification of its taxonomically most problematic family, Cucurbitaceae, have been the focus of several studies of the recent past ${ }^{17-20}$. Taxonomists over the years have differed on the delimitation of Cucumis, which was first described by Linnaeus in Species plantarum (1753). Numerous taxonomic 
treatments of Cucumis have been proposed since the pioneering work of Linnaeus ${ }^{8}$. Using maximum parsimony, maximum likelihood, and Bayesian inference analyses of sequence data from both the nuclear and chloroplast genomes, Ghebretinsae, Thulin and Barber have provided a comprehensive phylogeny of Cucumis and the traditionally related genera, Cucumella Chiovenda, Dicaelospermum C.B. Clarke, Mukia Arnott, Myrmecosicyos C. Jeffrey and Oreosyce Hooker f.8,9. Accordingly, the genus Cucumis from its erstwhile paraphyletic circumscription is recircumscribed by including the five genera of the subtribe cucumerinae Pax in compliance with the monophyly of Cucumis ${ }^{8-10}$.

\section{Foliar phenolics of Cucumis}

Two major chemical classes, viz., cucurbitacins and flavonoids dominate the phytochemistry of cucurbits. Cucurbitacins are bitter-tasting triterpenoids that are present in high concentrations in root tissue and are toxic to mammals. In contrast, the fruits of many species in this family are edible and used as foods, including pumpkin, watermelon, melon and cucumber ${ }^{21}$. Since the foliar phenolics generally contribute significantly to chemosystematics of both, angiosperms and gymnosperms, it is felt that an evaluation of the data available on the foliar flavonoid constitution of the recently defined Cucumis would be relevant. Survey of the flavonoid constitution of Cucumis has probably originated from the U.S. Vegetable Breeding Laboratory in 1969 during the screening for nematode resistance by Brown et al.,22. Twenty six compounds have been identification by paper chromatography from 15 Cucumis species. Based on the similarities in the distribution of flavonoids, they had grouped the studied species into two large complexes. The first consisted of $C$. africanus, $C$. heptadactylus, C. melo and C. myriocarpus and the second one composed of $C$. anguria, $C$. dipsaceus, C. ficifolius, C. prophetarum, C. pustulatus, and C. zeyheri. Cucumis hirsutus, C. humifructus, $C$. metuliferus, $C$. sagittatus, and $C$. sativus were each considered to be distinct from all the other species studied as they possessed distinct patterns unlike any other species.

Table 1 summarises the distribution of the naturally occurring foliar flavonoids of the genus recorded in literature. A conspicuous feature in all the studied Cucumis species is the biosynthesis of $O$-glucosylated- $C$-glucoflavones (Fig. 1). These compounds are also reported to be elaborated in eight further species of the genus, besides those noted in Table 1, according to Brown et al., ${ }^{22}$. In such glycoflavonoids occurring in nature, however, the hydrolysable O-glycosyl moiety can have two possible modes of linkage: either to a phenolic hydroxyl $\left(X-/ X^{\prime}-O\right)$ or to one of the hydroxyl functions of the $C$-glycosyl residue (X"-O). Consequently, two possible isomeric products of $C$-glycosylflavonoid-O-glycoside can result. Despite the fact that careful assignment of the characteristic UV, ${ }^{1} \mathrm{H}$ - and ${ }^{13} \mathrm{C}$-magnetic resonance data can distinguish the two isomers, there are occasions when investigators have concluded wrongly about the structure of their isolates ${ }^{29}$. For instance, 7-O$\beta$-D-glucopyranosyl-6- $C$ - $\beta$-D-glucopyranosylapigenin (saponarin) has been reported to occur in mature barley (Hordeum vulgare) leaves, along with lutonarin and its

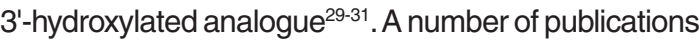
have described the structure of this glycoflavone, isolated from young green barley leaves, as $2 "-O-\beta-D$ glucopyranosyl-6- $C$ - $\beta$-D-glucopyranosylapigenin (5) ${ }^{32-}$ ${ }^{37}$. Markham and Mitchell have however subsequently established the major isolate from young green barley leaves also as saponarin and not compound 5, using authentic saponarin ${ }^{38}$. With little concern over the true structure of the isolates and admitting the literature reports in toto and also ignoring the site of glycosylation $\left(X / X^{\prime} / X^{\prime}\right), O$-glucosylated-C-glucoflavones, in general, appear to be the characteristically common foliar marker biochemical of the newly defined genus Cucumis L.

This hypothesis may be illustrated taking the following example. Three taxa are reported in literature as species of Melothria L. ${ }^{39}$, for which the flavonoid profile are available to date, in the context of their wide use in the traditional systems of medicines. viz., Melothria maderaspatana (L.) Cogn. ${ }^{3,4}$, M. heterophylla (Lour.) Cogn..$^{40-42}$ and $M$. perpusilla (Blume) Cogn. ${ }^{43}$. However, based on seed and stamen morphology, Jeffrey has divided Melothria into four genera, viz., Melothria L., Mukia Arn., Solena Lour., and Zehneria Endl. ${ }^{44}$, resulting in many species of Melothria getting transferred to Mukia, Solena and Zehneria. All these genera have three stamens. In Zehneria, the stamens are two-thecal whereas in Mukia and Solena, two stamens are two-thecal and the remaining stamen is one-thecal. Mukia has straight anther-thecae 
<smiles>[R]Oc1ccc(-c2cc(=O)c3c(O)c([R])c([R])c([R])c3o2)cc1[R]</smiles>

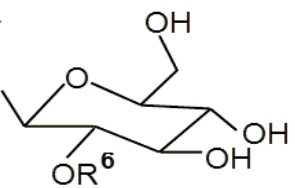<smiles>CCc1ccc(O)cc1</smiles><smiles>CC(=O)/C=C/c1ccc(O)c(O)c1</smiles>

$\beta$-D-glucopyranosy $(\mathrm{GL})$

4-hydroxy-1ethyl-benzene

$$
\text { cafeoyl }
$$
moiety (Ca)

\begin{tabular}{|c|c|c|c|c|c|c|c|}
\hline & Compound & $\mathrm{R}^{1}$ & $\mathrm{R}^{2}$ & $\mathrm{R}^{3}$ & $\mathrm{R}^{4}$ & $\mathrm{R}^{5}$ & $\mathrm{R}^{6}$ \\
\hline 1 & $\begin{array}{l}6-C-\beta \text {-D-glucopyranosylapigenin } \\
\text { (isovitexin) }\end{array}$ & $\mathrm{GI}$ & $\mathrm{H}$ & $\mathrm{H}$ & $\mathrm{H}$ & $\mathrm{H}$ & $\mathrm{H}$ \\
\hline 2 & $\begin{array}{l}\text { 8-C- } \beta \text {-D-glucopyranosylapigenin } \\
\text { (vitexin) }\end{array}$ & $\mathrm{H}$ & $\mathrm{GI}$ & $\mathrm{H}$ & $\mathrm{H}$ & $\mathrm{H}$ & $\mathrm{H}$ \\
\hline 3 & $\begin{array}{l}\text { 7-O- } \beta \text {-D-glucopyranosylisovitexin } \\
\text { (saponarin) }\end{array}$ & $\mathrm{Gl}$ & $\mathrm{H}$ & $\mathrm{Gl}$ & $\mathrm{H}$ & $\mathrm{H}$ & $\mathrm{H}$ \\
\hline 4 & 4'-O- $\beta$-D-glucopyranosylsaponarin & $\mathrm{GI}$ & $\mathrm{H}$ & $\mathrm{Gl}$ & $\mathrm{GI}$ & $\mathrm{H}$ & $\mathrm{H}$ \\
\hline 5 & $2 "-O-\beta-D-g l u c o p y r a n o s y l i s o v i t e x i n$ & $\mathrm{GI}$ & $\mathrm{H}$ & $\mathrm{H}$ & $\mathrm{H}$ & $\mathrm{H}$ & $\mathrm{Gl}$ \\
\hline 6 & 4'-X-di-O-glucopyranosylisovitexin & $\mathrm{Gl}$ & $\mathrm{H}$ & $\mathrm{H}$ & GI-GI & $\mathrm{H}$ & $\mathrm{H}$ \\
\hline 7 & $\begin{array}{l}\text { 8-(4-hydroxy-1-ethylbenzene)- } \\
\text { isovitexin }\end{array}$ & $\mathrm{Gl}$ & HEB & $\mathrm{H}$ & $\mathrm{H}$ & $\mathrm{H}$ & $\mathrm{H}$ \\
\hline 8 & 6-(4-hydroxy-1-ethylbenzene)-vitexin & HEB & $\mathrm{GI}$ & $\mathrm{H}$ & $\mathrm{H}$ & $\mathrm{H}$ & $\mathrm{H}$ \\
\hline 9 & $\begin{array}{l}6,8-d i-C-\beta-D-g l u c o p y r a n o s y l a p i g e n i n \\
\text { (Vicenin-2) }\end{array}$ & $\mathrm{Gl}$ & $\mathrm{Gl}$ & $\mathrm{H}$ & $\mathrm{H}$ & $\mathrm{H}$ & $\mathrm{H}$ \\
\hline 10 & $\begin{array}{l}\text { 6-C- } \beta \text {-D-glucopyranosylluteolin } \\
\text { (homoorientin) }\end{array}$ & $\mathrm{Gl}$ & $\mathrm{H}$ & $\mathrm{H}$ & $\mathrm{H}$ & $\mathrm{OH}$ & $\mathrm{H}$ \\
\hline 11 & $\begin{array}{l}\text { 8-C- } \beta \text {-D-glucopyranosylluteolin } \\
\text { (orientin) }\end{array}$ & $\mathrm{H}$ & $\mathrm{GI}$ & $\mathrm{H}$ & $\mathrm{H}$ & $\mathrm{OH}$ & $\mathrm{H}$ \\
\hline 12 & $\begin{array}{l}\text { 7-O- } \beta \text {-D-glucopyranosylhomoorientin } \\
\text { (lutonarin) }\end{array}$ & $\mathrm{H}$ & $\mathrm{GI}$ & $\mathrm{Gl}$ & $\mathrm{H}$ & $\mathrm{OH}$ & $\mathrm{H}$ \\
\hline 13 & $\begin{array}{l}\text { 6-C- } \beta \text {-D-glucopyranosyl-3',4',5- } \\
\text { trihydroxy-7-methoxy-flavone-4'-X- } \\
\text { di-O-glucopyranoside } \\
\text { (4'-X-di-O-glucosylswertiajaponin) }\end{array}$ & $\mathrm{Gl}$ & $\mathrm{H}$ & $\mathrm{CH}_{3}$ & GI-GI & $\mathrm{H}$ & $\mathrm{H}$ \\
\hline 14 & 6-C-diglucopyranosylapigenin & $\mathrm{Gl}-\mathrm{Gl}$ & $\mathrm{H}$ & $\mathrm{H}$ & $\mathrm{H}$ & $\mathrm{H}$ & $?$ \\
\hline 15 & 6-C-diglucopyranosylorientin & $\mathrm{Gl}-\mathrm{Gl}$ & $\mathrm{H}$ & $\mathrm{H}$ & $\mathrm{H}$ & $\mathrm{OH}$ & $?$ \\
\hline 16 & $\begin{array}{l}\text { X'"-cafeoyl-6-C-diglucopyranosyl- } \\
\text { apigenin }\end{array}$ & GI-GI & $\mathrm{H}$ & $\mathrm{H}$ & $\mathrm{H}$ & $\mathrm{H}$ & ? \\
\hline 17 & $\begin{array}{l}\text { X"'-cafeoyl- 6-C-diglucopyranosyl- } \\
\text { orientin }\end{array}$ & $\mathrm{Gl}-\mathrm{Gl}$ & $\mathrm{H}$ & $\mathrm{H}$ & $\mathrm{H}$ & $\mathrm{OH}$ & $?$ \\
\hline
\end{tabular}

? = linkage not established

Fig. 1: Name and Chemcial structures of the folair flavonoids reported from the genus Cucumis 
Table 1: Natural distribution of flavonoids in species and cultivar varieties of the genus Cucumis

\begin{tabular}{|c|c|c|c|c|c|c|c|c|c|c|c|c|c|c|c|c|c|}
\hline \multirow{2}{*}{$\begin{array}{l}\text { Species/ cultivar } \\
\text { varieties }\end{array}$} & \multicolumn{17}{|c|}{ Compound* } \\
\hline & 1 & 2 & 3 & 4 & 5 & 6 & 7 & 8 & 9 & 10 & 11 & 12 & 13 & 14 & 15 & 16 & 17 \\
\hline C. maderaspatanus ${ }^{23-24}$ & + & + & + & & & & & & & + & + & + & & & & & \\
\hline C. melo var. Doublon ${ }^{25}$ & & & & & & & & & & & & & & + & + & + & + \\
\hline C. metuliferus ${ }^{26}$ & & & & & + & & & & & & & & & & & & \\
\hline C. myriocarpus ${ }^{26}$ & + & & & & + & & & & & + & & & & & & & \\
\hline C. sativus s $^{26,27}$ & + & + & & & + & + & + & + & & + & + & & + & & & & \\
\hline C. sativus Mustang ${ }^{28}$ & + & & + & + & & & & & + & & & & & & & & \\
\hline C. sativus Cezar ${ }^{26}$ & + & & & & + & + & & & & + & & & + & & & & \\
\hline C. sativus Hela ${ }^{26}$ & & & & & + & + & & & & & & & + & & & & \\
\hline C. sativus Monastyrski²6 & & & & & + & & & & & + & & & & & & & \\
\hline C. sativus Olimp ${ }^{26}$ & & & & & + & & & & & & & & & & & & \\
\hline C. sativus Polan ${ }^{26}$ & & & & & + & + & & & & & & & + & & & & \\
\hline C. sativus Delicius ${ }^{26}$ & + & & & & + & + & & & & + & & & + & & & & \\
\hline
\end{tabular}

*The names and chemical structures of the compounds are described in Fig. 1

and verrucose seeds, whereas Solena has oblique, curved anther-thecae and smooth seeds. Thus, Jeffrey has re-established the genera: Zehneria Endl., characterized by its three 2-thecous stamens, Solena Lour., by its peculiar obliquely triplicate anther-thecae, and Mukia Arn., by its tumid seeds and clustered flowers, as distinct from Melothria L. into which they had been sunk by Cogniaux ${ }^{39}$. Melothria is presently an entirely New World genus of plants with long-stalked fruits and male racemes, compressed seeds, and 3 stamens, two of which are 2-thecous and the other, 1-thecous. According to this revision, M. heterophylla (Lour.) Cogn. is now Solena heterophylla Lour. subsp. heterophylla ${ }^{45}$ and $M$. perpusilla (Blume) Cogn. is Zehneria bodinieri (H. Lév. ${ }^{45}$. O-glucosylated- $C$ glucoflavones, viz., 7-O- $\beta$-D-glucopyranosylisovitexin (3) and 7-O- $\beta$-D-glucopyranosylhomoorientin (12) are reported only from $C$. maderaspatanus L. ${ }^{23-24}$ and has not been reported yet from either $S$. heterophylla Lour. or from $Z$. bodinieri (H. Lév.). From the leafextract of $S$. heterophylla Lour., 1,2,4,6-tetra-Ogalloyl- $\beta$-D-glucopyranose, 3,4,5-trihydroxybenzoic acid (gallic acid), 3-O-rutinosylquercetin (rutin),
7-O- $\beta$-D-glucopyranosylluteolin and 7-O- $\beta$-Dglucopyranosylapigenin alone and no $C$-glycoflavone has been reported until now. Similarly, 4'-O- $\beta-D-$ galactosylquercetin, 3-O- $\beta$-D-glucosyl $(1 \rightarrow 2)-\beta-D$ glucosylkaempferol and 3-O- $\beta$-D-glucosyl-( $1 \rightarrow 2)$ $\beta$-D-galactosylquercetin7- $O-\beta$-D-glucoside alone have been isolated till date from $Z$. bodinieri (H. Lév.).

\section{CONCLUSIONS}

The occurrence of compounds 3 and 12 in C. maderaspatanus $\mathrm{L}$. is chemosystematically in harmony with the recent revision of the genus Cucumis L. The present study is however subject to the limitations that the flavonoid profile available in literature to date is only limited and requires more study reports to gain larger sample size. Further, the reports of partially/incompletely characterized compounds 14-17 as well as those reported from eight other species by Brown et al. ${ }^{22}$ has restricted the specificity of the marker compound.

\section{REFERENCES}

1. Crase B, In: Short P.S., Cowie, I.D. (eds), Flora of the Darwin Region. (Northern Territory Herbarium, Department of Natural Resources, Environment, the Arts and Sport). 1: 1-17 (2011).
2. Petrus A.J.A., Asian J Chem, 24: 2361 (2012).

3. Petrus A.J.A., Indian J. Nat. Prod. Resour., 4: 9 (2013).

4. Petrus A.J.A., Phcog. J., 4 (34): 1 (2012). 
5. Sebastian P., Schaefer H., Telford I.R.H., Renner S.S., PNAS, 107: 14269 (2010).

6. Jeffrey C., In: Milne-Redhead, E., Polhill, R.M. (eds), Flora of Tropical East Africa, Crown Agents for Overseas Governments and Administrations: London, (1967).

7. Renner S.S., Schaefer H., Kocyan A., BMC Evolutionary Biol., 7: 58 (2007).

8. Ghebretinsae A.G., Thulin M., Barber J.C., Amer. J. Bot., 94: 1256 (2007).

9. Ghebretinsae A.G., Thulin M., Barber J.C. Novon 17: 176 (2007)

10. Schaefer H., Blumea, 52: 165 (2007).

11. Hutchinson J., The families of flowering plants, 2nd edn. Oxford University Press, Oxford (1959).

12. Davis P.H., Heywood V.H., Principles of angiosperm taxonomy. Robert E Kreiger Publishing Company, New York (1973).

13. Sharma G., Proc. Natl. Acad. Sci., India, Sect. B Biol. Sci. 83: 141 (2013).

14. Kay C.D., Br. J. Nutr., 104, S91 (2010).

15. J.P. Noudogbessi, G.A. Alitonou, T. Djenontin, F. Avlessi, G. Figueredo, P. Chalard, J.C., Chalchat and D.C.K. Sohounhloue, Orient J. Chem., 29(1): 59-67 (2013).

16. Cronquist A., Plant Syst. Evol. Suppl. 1: 179 (1977).

17. Jeffrey C., Bot. Zhurn., 90: 332 (2005).

18. Zhang L.-B., Simmons M.P., Kocyan A., Renner S.S., Molec. Phylog. Evol., 39: 305 (2006).

19. Schaefer H., Heibl C., Renner S.S., Proc. Roy. Soc. London, Ser. B, Biol. Sci. 276: 843 (2009).

20. Schaefer H., Renner S.S., Taxon 60: 122 (2011).

21. P.K. Mukherjee, N.K. Nema, N. Maity and B.K. Sarkar, Fitoterapia 84: 227 (2013).

22. Brown G.B., Deakin J. R., Wood M.B., J. Amer. Soc. Hort. Sci., 94: 231 (1969).

23. Petrus A.J.A., Bhuvaneshwari N., Alain J.A.L., Indian J. Nat. Prod. Resour., 2: 34 (2011).

24. Petrus A.J.A., Bhuvaneshwari N., Asian J. Chem., 24: 1261 (2012).

25. Monties B., Bouillan M.L., Chopin J., Phytochemistry,15: 1053 (1976).

26. Krauze-Baranowska M., Cisowski W., Biochem. Systemat. Ecol., 29: 321 (2001).

27. McNally D.J., Wurms K.V., Labbé C., Quideau
S., Bélanger R.R., J. Nat. Prod., 66: 1280 (2003).

28. Abou-Zaid M.M., Lombardo D.A., Kite G.C., Grayer R.J., Veitch N.C., Phytochemistry 58: 167 (2001).

29. Petrus A.J.A., Bhuvaneshwari N., UGC-SAP, DST and CSIR sponsored National Seminar on New Frontiers in Chemistry, Annamalai University, Annamalai Nagar, India, (2010).

30. F. Hatamjafari and S.A. Goorabi, Orient J. Chem., 29(2): 759-762 (2013).

31. Chopin J., Bouillant M.L., In: Harborne J.B, Mabry T.J., Mabry H., (eds.) The Flavonoids. Chapman \& Hall Ltd., London pp. 650-667 (1975).

32. Osawa T., Katsuzaki H., Hagiwara Y., Hagiwara H., Shibamoto T., J. Agric. Food Chem. 40: 1135 (1992).

33. Kitta K., Hagiwara Y. and Shibamoto T., J. Agric. Food Chem. 40: 1843 (1992).

34. Nishiyama T., Hagiwara Y., Hagiwara $H$. and Shibamoto T., J. Amer. Oil Chemists Soc., 70: 911 (1993).

35. Miyake T., Hagiwara Y., Hagiwara H. and Shibamoto T., Symposium of Functional Foods, 213 ${ }^{\text {th }}$ ACS National Meeting (1997).

36. Miyake T., Shibamoto T., J. Agric. Food Chem. 45: 1819 (1997).

37. Miyake T., Shibamoto T., J. Agric. Food Chem. 46: 3694 (1998).

38. Markham K.R., Mitchell K.A., Z. Naturforsch., 58c: 53 (2003).

39. Cogniaux A., In A.L.P.P. de Candolle and A.C.P. de Candolle [eds.], Monographiae phanerogamarum, 3: 325-951, 953-954. G. Mason, Paris, France (1881).

40. Cho Y.H., Kim J.H., Sim G.S. Lee B.C., Pyo H.B., Park H.D., J. Cosmet. Sci. 57: 279 (2006).

41. Mondal A., Maity T.K., Pal D.K., Pharm. Biol., 50: 1151 (2012).

42. Lalhriatpuii T.C., Ghosh S.K., Achari B., Lalawmpuii P.C., Vanlalruata R, J. Pharm. Res., 1: 15 (2013).

43. Langoljam R.D., Kongbrailatpam B.D., Laitonjam W.S., Indian J. Chem., 44B: 1291 (2005).

44. Jeffrey C., Kew Bulletin 15: 337 (1962).

45. Renner S.S., Pandey A.K. PhytoKeys 20: 53 (2013). 